\title{
The Princeton Fugitive Slave: The Trials of James Collins Johnson
}

\section{Lolita Buckner Inniss}

New York: Fordham University Press, 2019

ISBN: 9780823285341

DOI: $\underline{\text { https://doi.org/10.14713/njs.v7i1.243 }}$

Lolita Buckner Inniss's The Princeton Fugitive Slave: The Trials of James Collins Johnson is an academic reconsideration of James Collins Johnson, a Black man who escaped enslavement in Maryland and traveled to Princeton, New Jersey, where he was caught and tried as a fugitive slave. He was then purchased by a woman who had ties to the college. For over a century, public memory depicted Princeton as Johnson's saving grace - a sanguine respite from slavery. However, Inniss, herself a graduate of Princeton, crafts an alternative narrative of the racialized and paternalistic politics that placed the body and labor of Johnson at Princeton for the remainder of his life. She argues that the memory of slavery is much like the memory of Johnson himself: people often view slavery as a monolithic institution frozen in time, but investigations of the lives of individuals demonstrate how slavery was a series of traumatic, tragic events that continually and profoundly shaped the personal lives of the enslaved and their descendants.

We may never understand the sweep and scope of Johnson's life, nor his thoughts, because Johnson himself left very few documents apart from a handful of oral histories conducted and transcribed by white students and alumni. Inniss instead tries to contextualize Johnson's life within the experiences of his family members, neighbors, and other contemporaries. The author uses legal sources, personal correspondence, and University administration files to break through the romanticized memories about nineteenth century Princeton and instead articulates a campus of contradictions: a growing number of pro-slavery Southern students and widespread support for the American Colonization Society's commitment to deportation to Africa as a pre-condition for Black freedom amongst northern students and faculty. Inniss makes Johnson's biography political by 
weaving in and out of his private life and the broader historical context on campus and in the community to find the truth of Johnson's lived experience. From his escape from a plantation on the Eastern Shore of Maryland in the late 1830s to Princeton, and his arrest as a 'fugitive slave' in 1843 and eventual life thereafter in pseudo-freedom in New Jersey, Inniss employs a thickly descriptive approach to local legal and social history to argue that Johnson's life was complicated, difficult, and just as important as the lives of the men he served. Her approach and her grasp of genealogical tools and family histories shines, especially concerning Johnson's trial where she reveals new questions about the money raised to purchase Johnson.

The popular narrative of the trial portrayed the Princeton community as benevolent masters who give Johnson his freedom after his trial; however, Inniss demonstrates that this was an oversimplified story crafted by white men affiliated with the college and excludes critical information about Johnson's life. Johnson could not testify at his own trial according to a New Jersey law that prohibited Black people from testifying, so he relied on his lawyers and white witnesses. Johnson's former enslaver Severn Teackle Wallis served as the opposing counsel in the case. Wallis called several witnesses, including family members and Princeton students. The judge allowed Johnson a jury trial despite the decision in Prigg v. Pennsylvania issued just months earlier that held most state-enacted protections for alleged fugitive enslaved people, including the right to a jury trial, violated the Fugitive Slave Act of 1793. The jury deliberated for only thirty minutes before deciding to return him to bondage.

Inniss's analysis offers new insight on Johnson's life after the verdict by focusing on the woman who stepped forward with the money to purchase Johnson, Theodosia Ann Mary Prevost. Inniss investigates her connections with Princeton administration including the president of the college and local Quaker anti-slavery activists. The author suggests that it is more likely that anti- 
slavery activists, rather than Princeton administrators, raised the money necessary to keep Johnson in New Jersey. Regardless of who organized the money-this transaction was not a gift. Johnson served Prevost for a term of 5 years and at the rate of $\$ 100$ per year. The money kept him from returning to the Maryland plantation, but it did not alter Johnson's reality: "I never got no free papers. Princeton College bought me; Princeton College owns me; and Princeton College has got to give me my living (98).”

Regardless of how she funded the purchase, Johnson was sold to Prevost. Even if she never intended to fully "enslave" Johnson, his legal status as a slave remained unchanged after the trial. Prevost presented a term slavery agreement-he was technically enslaved to Prevost and he had to work off the debt for the purchase and remain in Princeton long-term. He remained at the University to pay his debt, working as a 'college servant,' a broad classification of duties including cleaning rooms, maintaining students' belongings, cleaning chimneys, emptying chamber pots, and cleaning shoes. Through her detailed account, the author focuses on the ways Johnson paid off his debt, rented a shop to sell used clothes and furniture, and purchased a home in the face of the racism he faced on and off campus.

Through her dogged pursuit of Johnson's story, Inniss presents a powerful understanding of Johnson's life that unravels the dehumanizing narrative that persisted for generations of students on Princeton's campus; however, the analysis could benefit from comparing the stories of similar people at Universities. The author missed an opportunity to engage with a broader literature about enslavement at institutions and universities, such as Jennifer Oast's Forgotten Masters: Institutional Slavery in Virginia, 1680-1860, Mark Auslander's The Accidental Slaveowner: Revisiting a Myth of Race and Finding an American Family, or Maurie D. McInnis and Louis P. Nelson's Educated in Tyranny: Slavery at Thomas Jefferson's University. Drawing upon these 
comparisons in the text would have added new insight into slavery, memory, and college campuses more broadly. Though Innis does not draw specific connections to other institutions, her work is an important step towards creating a more truthful history of the relationships between black community members and institutions of higher education at the turn of the $20^{\text {th }}$ century.

\section{Ashley Schmidt, PhD \\ University of Virginia}

